\title{
Controlling the Doping Depth in Silicon Micropillars
}

\author{
Amal Kabalan \\ Department of Electrical and Computer Engineering, Bucknell University, Lewisburg, PA 17837, USA; \\ aak012@bucknell.edu
}

Received: 12 June 2020; Accepted: 24 June 2020; Published: 1 July 2020

check for updates

Featured Application: The proposed method can be utilized to fabricate micropillar solar cells.

\begin{abstract}
Micropillar arrays with radial p-n junctions are attractive for photovoltaic applications, because the light absorption and carrier collection become decoupled. The main challenge in manufacturing radial $\mathrm{p}-\mathrm{n}$ junctions is achieving shallow (dopant depth $<200 \mathrm{~nm}$ ) and heavy doping $\left(>10^{20} \mathrm{~cm}^{-3}\right.$ ) that will allow the formation of a quasi-neutral region (QNR) and space charge region (SCR) in its tiny geometry. This experimental study investigates an approach that allows shallow and heavy doping in silicon micropillars. It aims to demonstrate that silicon dioxide $\left(\mathrm{SiO}_{2}\right)$ can be used to control the dopant penetration depth in silicon micropillars.
\end{abstract}

Keywords: micropillars; silicon; shallow doping

\section{Introduction}

Micropillar arrays have been of interest for photovoltaic applications because structured patterning of a planar silicon surface leads to enhanced light trapping efficiency [1-7]. This enhancement leads to an increase in efficiency between 1.5-11\% [8] and in turn enables solar cells based on thin layers $(<100 \mu \mathrm{m})$, thereby greatly reducing start-up materials cost [9-11]. Among the various surface structures possible, micropillar arrays with radial $\mathrm{p}-\mathrm{n}$ junctions are particularly attractive, because the light absorption and carrier collection become decoupled [12]. In other words, incident light is absorbed along the long wire axis, while generated charge carriers can be collected along the relatively short radial direction [13]. The main challenge in forming radial $\mathrm{p}-\mathrm{n}$ junctions is achieving shallow doping that will allow the formation of a quasi-neutral region (QNR) and space charge region (SCR) in its tiny geometry [14,15]. Figure $1 \mathrm{a}$ is a representation of the desired radial $\mathrm{p}-\mathrm{n}$ junction [15]. Figure $1 \mathrm{~b}$ is a representation of the radial $\mathrm{p}-\mathrm{n}$ junction obtained when the pillars are doped using the same procedure that is used to dope planar silicon wafers [16,17]. Another challenge is reducing the surface defects generated by the direct etching of the semiconductor, which may cause a lower carrier collection efficiency and degradation of the cell performance [18-21]. Current etching and doping techniques result in rough surfaces with major defects that act as favorable sites for surface recombination. This paper aims to demonstrate that silicon dioxide $\left(\mathrm{SiO}_{2}\right)$ can be used as a layer to achieve shallow (dopant depth $<200 \mathrm{~nm})$ and heavy $\left(>10^{20} \mathrm{~cm}^{-3}\right)$ doping in micropillars. The reason the above metrics were used $\left(<200 \mathrm{~nm}\right.$ and $\left.>10^{20} \mathrm{~cm}^{-3}\right)$ is because a study has shown that junctions with depth larger than $200 \mathrm{~nm}$ resulted in 20\% reduced efficiency [22]. Another study [23-25] also revealed that junctions with low dopant concentration $\left(<2 \times 10^{19} \mathrm{~cm}^{-3}\right)$ did not give properly functioning diodes. 


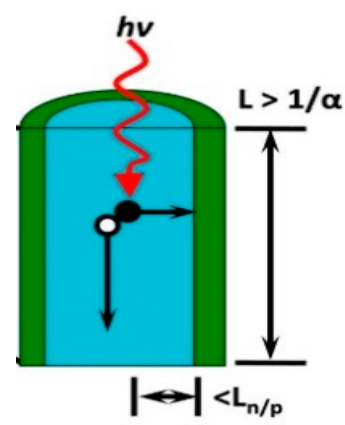

(a)

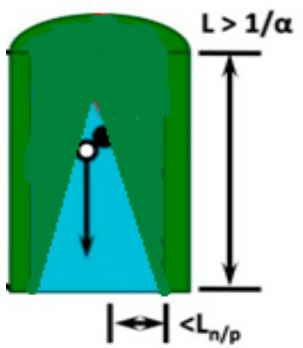

(b)

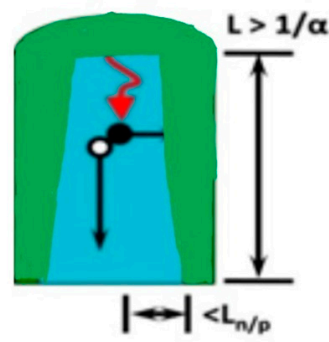

(c)

Figure 1. Image (a) represents the desired radial p-n junction [15], image (b) represents the radial $p-n$ junction obtained when the micropillars were doped with the same method used to dope planar silicon wafers, and image (c) is the potential radial $\mathrm{p}-\mathrm{n}$ junction with the proposed doping method.

\section{Materials and Methods}

A p-type $\mathrm{Cz}$ (100) wafer with a resistivity of 5-10 $\Omega$-cm was used for the experiments. All wafers were chemically cleaned. The cleaning steps involve preparing a solution of a mixture of $\mathrm{H}_{2} \mathrm{SO}_{4}$ and $\mathrm{H}_{2} \mathrm{O}_{2}$ with a 5:1 ratio (Piranha solution). Piranha is mainly used to remove heavy organic materials, like resist and other organic contamination. It works as an oxidant and attacks the hydrocarbons [25]. Vertical silicon micropillars were fabricated using dry etching. The microdisk arrays were patterned in LOR3A and Shipley S1805 photoresist using photolithography. After the pattern was developed, titanium was deposited to a thickness of $50 \mathrm{~nm}$, and nickel was evaporated to a thickness of $200 \mathrm{~nm}$. The lift off process was performed to leave $4 \mu \mathrm{m}$ circles of the evaporated metals. The samples were etched for $60 \mathrm{~min}$.

Plasma Enhanced Chemical Vapor Deposition (PECVD) was used to deposit $50 \mathrm{~nm}$ of $\mathrm{SiO}_{2}$ at a rate of $10.5 \mathrm{~nm} / \mathrm{min}$. The samples were annealed at $950{ }^{\circ} \mathrm{C}$ for $20 \mathrm{~s}$ using Rapid Thermal Annealing (RTA). In sample A, the phosphorus was spun-on doped and driven into the sample by rapid thermal annealing. In sample $\mathrm{B}, \mathrm{SiO}_{2}$ was used between the dopant and the substrate in order to reduce the diffusion of phosphorus into the substrate.

In order to perform I-V measurements, aluminum metal contacts were deposited on the top and back of the silicon substrates. The procedure is as follows: (1) spin dope boron on the back of the intrinsic silicon substrate; (2) anneal boron dopant at $950{ }^{\circ} \mathrm{C}$ for five minutes using rapid thermal annealing process; and (3) deposit the aluminum metal contacts on top of the wafer using electron e-beam. The thickness of the metal was $250 \mathrm{~nm}$. A $1 \mathrm{~cm} \times 1 \mathrm{~cm}$ mask was used to deposit the top contacts, with the dimensions of the contact being $2 \mathrm{~mm} \times 2 \mathrm{~mm}$ (5) deposit aluminum contacts on the bottom of the intrinsic silicon.

\section{Results}

Figure 2 is a Scanning Electron Microscope (SEM) image of the silicon micropillars with no $\mathrm{SiO}_{2}$ deposition. It was seen that the diameter of the pillars was $3.952 \mu \mathrm{m}$. Figure 3 shows a SEM image of the silicon micropillar with silicon oxide deposited on the pillars. It was seen that the diameter of the pillars was $4.170 \mu \mathrm{m}$.

X-ray Photoelectron Spectroscopy (XPS) measurements were performed in order to study the depth profile of phosphorus in all the samples. XPS is a tool used for surface analysis. The X-ray depth penetration is about $10 \mu \mathrm{m}$, but only the top $10 \mathrm{~nm}$ can emit photoelectrons. Figure 4 shows the dopants depth and atomic percentage of Phosphorus in sample A (no oxide layer) and sample B (oxide layer). Sample A showed that with no $\mathrm{SiO}_{2}$ layer, the phosphorus concentration at $5 \mathrm{~nm}$ depth was $8 \%\left(4 \times 10^{21} \mathrm{~cm}^{-3}\right)$ and the atomic percentage dropped to $\approx 2 \%$ at $15 \mathrm{~nm}$. Sample B showed that with $\mathrm{SiO}_{2}$ used as a blocking layer, the phosphorus concentration was $4 \%$ at the surface and dropped to 
$2 \%$ at $15 \mathrm{~nm}$. These results show that the concentration of phosphorus and the slope of concentration vs. depth can be controlled by using $\mathrm{SiO}_{2}$.

Figure 5 depicts the I-V profile of sample B (oxide layer). The voltage was swept from $-5 \mathrm{~V}$ to $5 \mathrm{~V}$, and the current was measured. It was observed that a Schottky contact was obtained, where at $5 \mathrm{~V}$ the dark current was $0.2 \mathrm{~mA} / \mathrm{cm}^{2}$ and the light current was $0.3 \mathrm{~mA} / \mathrm{cm}^{2}$. The addition of the silicon oxide insulating layer could play a role in enhancing the solar cell's current output by reducing the cell's saturation current.

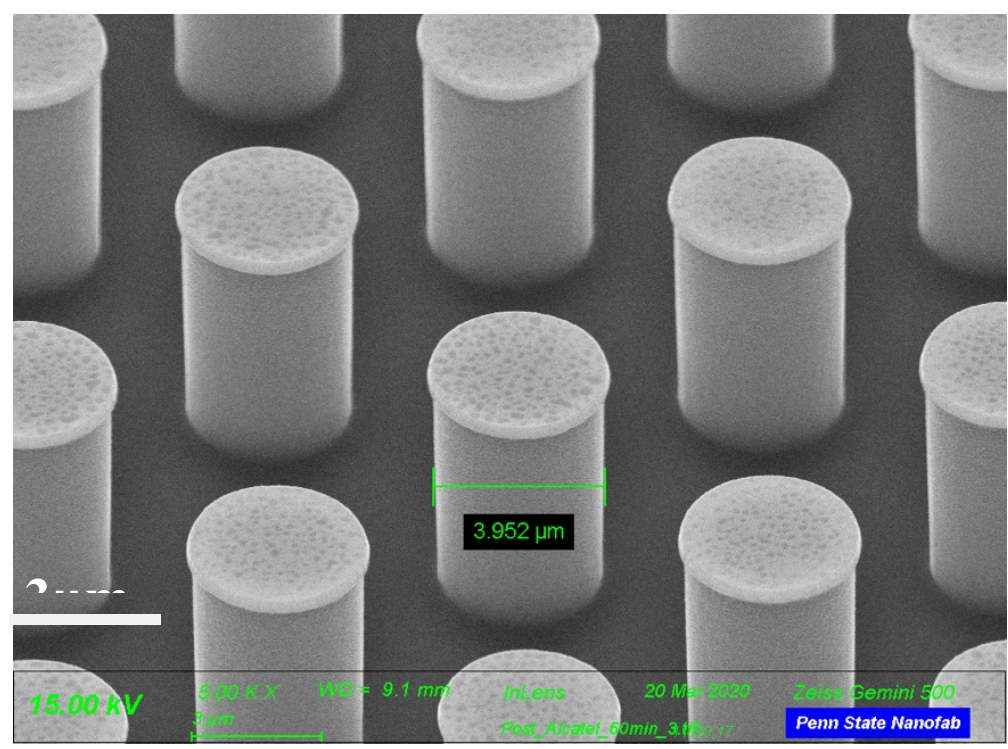

Figure 2. Micropillars without oxide layer. The diameter of the pillar is $3.952 \mu \mathrm{m}$.

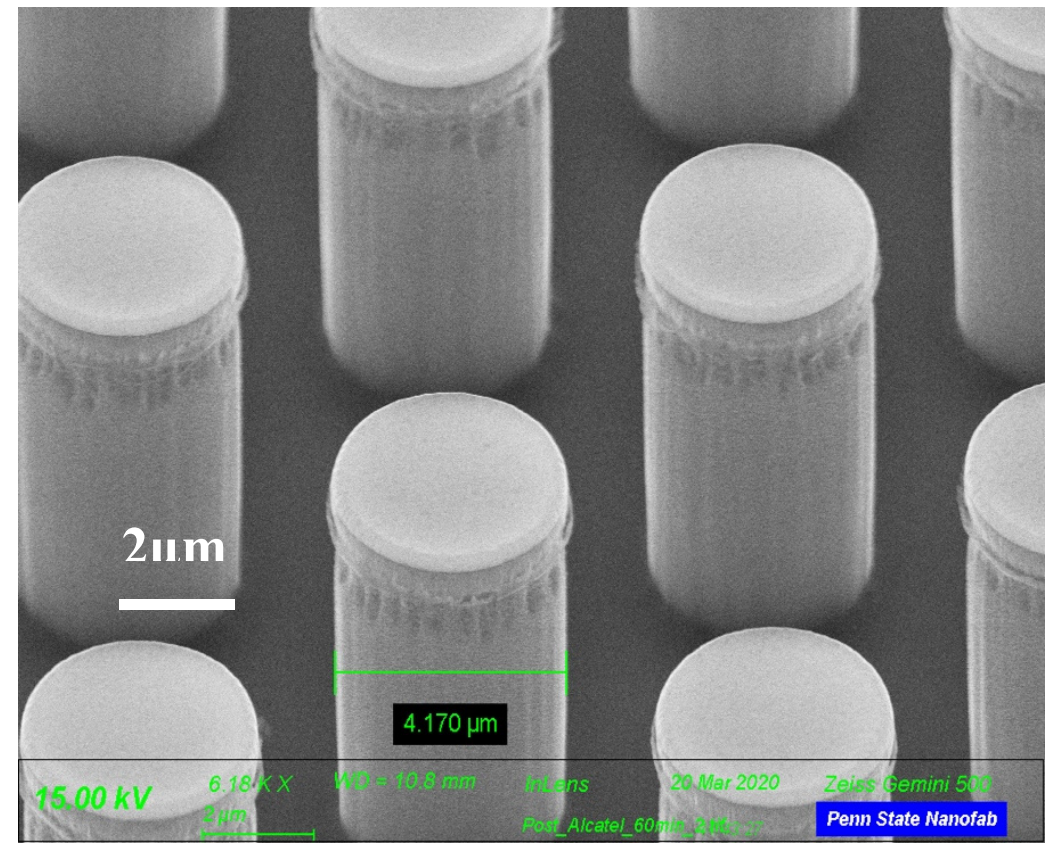

Figure 3. Micropillars with oxide layer. The diameter of the pillar is $4.17 \mu \mathrm{m}$. 


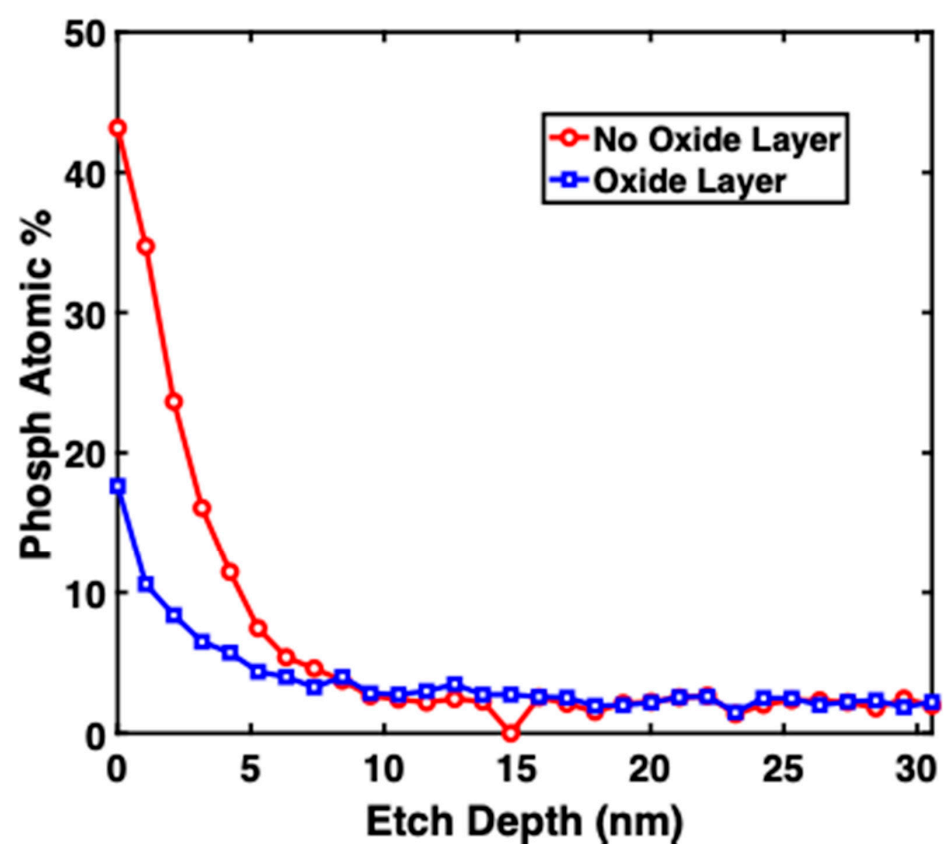

Figure 4. Atomic percentage of phosphorous in sample A (no oxide layer/legend with red circles) and sample B (oxide layer/legend with blue squares).

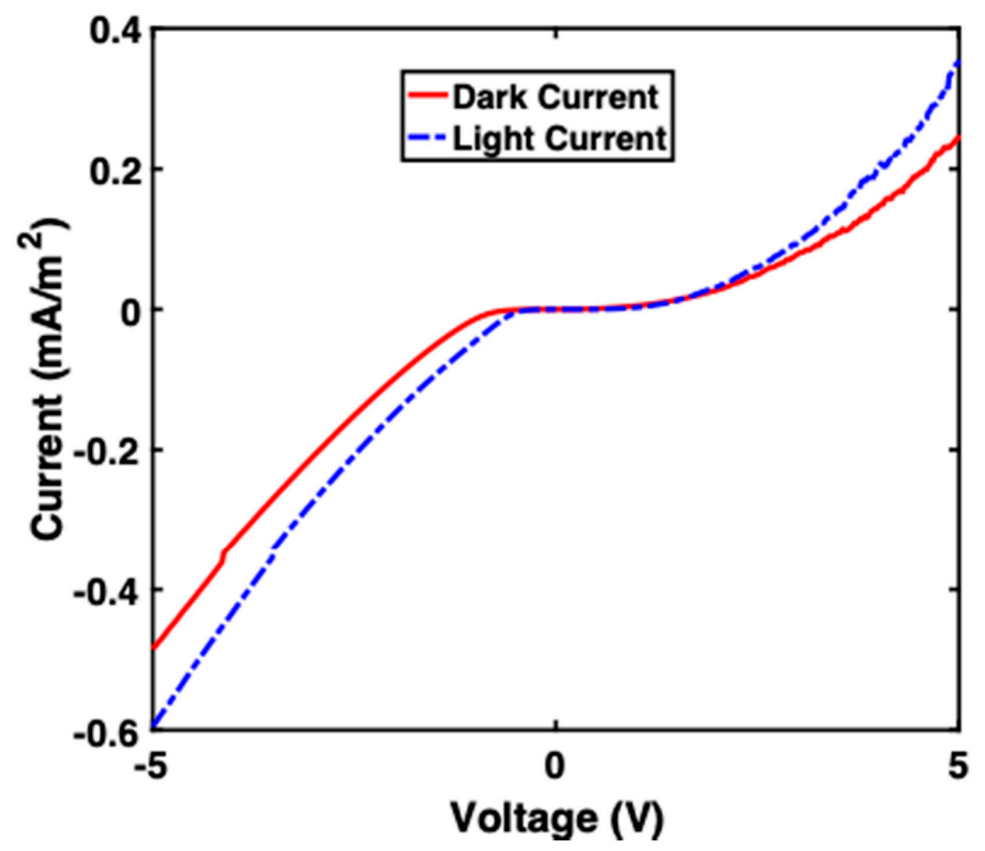

Figure 5. I-V profile of sample B (the sample with an oxide layer).

A p-n junction is characterized by its saturation current, $I_{0}$, which is the sum of the minority saturation current and majority carrier saturation current. It is known that high saturation current hurts the performance of solar cells. Adding an insulating layer between the semiconductor and the metal can reduce the saturation current due to the majority carriers without impacting significantly the short-circuit current which is a result of minority carriers tunneling through the insulator, as shown in Figure 6. The main cause of this phenomena is because the electric field drives the minority carriers towards the barrier, where they can accumulate to tunnel through. The majority carriers on the other hand are pushed away from the interface electric field. This means slowing their passage can significantly reduce their current flow. Thus, creating a Metal-Insulator-Semiconductor (MIS) 
contact instead of a Metal-Semiconductor (MS) contact can have the added advantage of reducing the saturation current of the solar cell.

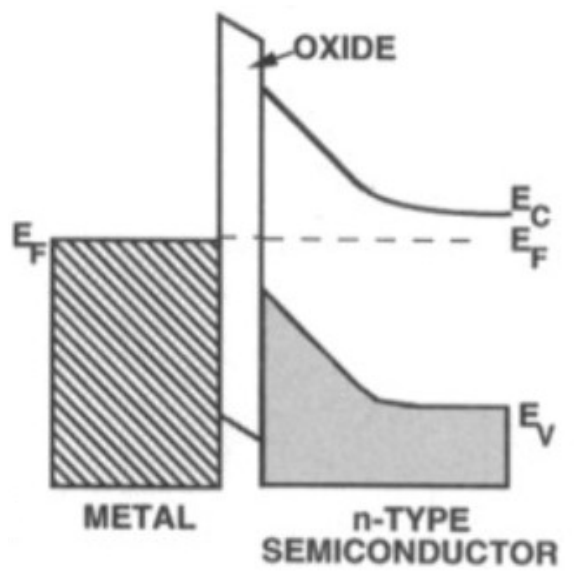

Figure 6. Energy band schematic of a metal-oxide-semiconductor interface [26].

\section{Conclusions}

The above results demonstrate that silicon oxide, which can be used as a passivating layer [27], can also be used to achieve a shallow doping depth in silicon wafers. It was demonstrated that the doping profile can be varied by doping through a silicon oxide layer. Two main points need to be studied further: (1) the doping level required in micropillar solar cells applications $>10^{20} \mathrm{~cm}^{-3}$ which is $\approx 5 \%$ concentration of phosphorus. The above experiments show a doping level greater than $9 \%$. Detecting a doping level of $5 \%$ and below might be challenging with the XPS. Another tool, such as the Atomic Probe Topography or Secondary Ion Mass Spectroscopy, is recommended; (2) the second point is whether activation of phosphorus is achieved by the rapid thermal annealing. In order for a $\mathrm{p}-\mathrm{n}$ junction to form, the phosphorus has to be part of the silicon lattice in order to form a covalent bond. One possible solution is to increase the thickness of the $\mathrm{SiO}_{2}$ layer so that the lower concentration of phosphorus penetrates silicon. Experimenting with changing the $\mathrm{SiO}_{2}$ layer thickness and measuring the I-V curve to obtain information about the nature of the junction and type of contact is recommended as the next step.

Funding: This research received no external funding

Conflicts of Interest: The authors declare no conflict of interest.

\section{References}

1. Hu, L.; Chen, G. Analysis of optical absorption in silicon nanowire arrays for photovoltaic applications. Nano Lett. 2007, 7, 3249-3252. [CrossRef]

2. Huang, Y.-F.; Chattopadhyay, S.; Jen, Y.-J.; Peng, C.-Y.; Liu, T.-A.; Hsu, Y.-K.; Pan, C.-L.; Lo, H.-C.; Hsu, C.-H.; Chang, Y.-H. Improved broadband and quasi-omnidirectional anti-reflection properties with biomimetic silicon nanostructures. Nat. Nanotechnol. 2007, 2, 770-774. [CrossRef] [PubMed]

3. Tsakalakos, L.; Balch, J.; Fronheiser, J.; Korevaar, B.A.; Sulima, O.; Rand, J. Silicon nanowire solar cells. Appl. Phys. Lett. 2007, 91, 233117. [CrossRef]

4. Muskens, O.-L.; Rivas, J.G.; Algra, R.E.; Bakkers, E.P.A.; Lagendijk, A. Design of light scattering in nanowire materials for photovoltaic applications. Nano Lett. 2008, 8, 2638-2642. [CrossRef] [PubMed]

5. Zhu, J.; Yu, Z.; Burkhard, G.F.; Hsu, C.-M.; Connor, S.T.; Xu, Y.; Wang, Q.; McGehee, M.D.; Fan, S.; Cui, Y. Optical absorption enhancement in amorphous silicon nanowire and nanocone arrays. Nano Lett. 2009, 9 , 279-282. [CrossRef]

6. Kelzenberg, M.D.; Boettcher, S.W.; Petykiewicz, J.A.; Turner-Evans, D.B.; Putnam, M.C.; Warren, E.L.; Spurgeon, J.M.; Briggs, R.M.; Lewis, N.S.; Atwater, H.A. Enhanced absorption and carrier collection in Si wire arrays for photovoltaic applications. Nat. Mater. 2010, 14, 239-244. [CrossRef] 
7. Zhu, J.; Hsu, C.M.; Yu, Z.; Fan, S.; Cui, Y. Nanodome solar cells with efficienct light management and self-cleaning. Nano Lett. 2010, 10, 1979-1984. [CrossRef]

8. Watson, T.; Amos, A. Comparison of the device physics principles of planar and radial p-n junction nanorod solar cells. J. Appl. Phys. 2005, 97, 114302.

9. Gunawan, O.; Waung, K.; Fallahazad, B.; Zhang, Y.; Tutuc, E.; Guha, S. High performance wire-array silicon solar cells. Prog. Photovolt. Res. Appl. 2011, 19, 307-3012. [CrossRef]

10. Sturmberg, B.; Dossou, K.; Botten, L.; Asatryan, A.; Poulton, C.; Sterke, M.; McPhedran, R. Modal analysis of enhanced absorption in silicon nanowire arrays. Opt. Express 2011, 19, A1067-A1081. [CrossRef]

11. Tsakalakos, L. Nanostructures for photovoltaics. Mater. Sci. Eng. 2008, 62, 175-189. [CrossRef]

12. Kim, S.; Day, R.; Cahoon, J.; Kempa, T.; Song, K.; Park, H.; Lieber, C. Tuning light absorption in core/shell silicon nanowire photovoltaic devices through morphological design. Nano Lett. 2012, 12, 4971-4976. [CrossRef] [PubMed]

13. Gharghi, M.; Fathi, E.; Kante, B.; Sivoththaman, S.; Zhang, X. Heterojunction silicon microwire solar cells. Nano Lett. 2012, 12, 6278-6282. [CrossRef] [PubMed]

14. Kim, J.; Kim, M.; Kim, H.; Song, K.; Lee, E.; Kim, D.-W.; Yun, J.-H.; Choi, B.; Lee, S.; Jeong, C.; et al. Effective light management of three-dimensionally patterned transparent conductive oxide layers. Appl. Phys. Lett. 2012, 101, 143904. [CrossRef]

15. Krogstrup, P.; Jørgensen, H.I.; Heiss, M.; Demichel, O.; Holm, J.V.; Aagesen, M.; Nygard, J.; Fontcuberta, A. Single-nanowire solar cells beyond the Shockley-Queisser limit. Nat. Photonics 2013, 7, 306-310. [CrossRef]

16. Koren, E.; Berkovitch, N.; Rosenwaks, Y. Measurement of active dopant distribution and difussion in individual silicon nanowires. Nano Lett. 2010, 10, 1163-1167. [CrossRef]

17. Perea, D.; Hemesath, E.; Schwallbach, E.; Lensch-Falk, J.; Voorhees, P.; Lauhon, L. Direct measurement of dopant distribution in an individual vapour-liquid-solid nanowirer. Nat. Nanotechnol. 2009, 4, 315-319. [CrossRef]

18. Priolo, F.; Gregorkiewicz, T.; Galli, M.; Krauss, T.F. Silicon nanostructures for photonics and photovoltaics. Nat. Nanotechnol. 2014, 9, 19-32. [CrossRef]

19. Jeong, S.; McGehee, M.D.; Cui, Y. All-back-contact ultra-thin silicon nanocone solar cells with 13.7\% power conversion efficiency. Nature Commun. 2013, 4, 2950. [CrossRef]

20. Wallentin, J.; Anttu, N.; Asoli, D.; Huffman, M.; Aberg, I.; Magnusson, M.H.; Siefer, G.; Fuss-Kailuweit, P.; Dimroth, F.; Witzigmann, B.; et al. InP nanowire array solar cells achieving $13.8 \%$ efficiency by exceeding the ray optics limit. Science 2013, 339, 1057-1060. [CrossRef]

21. Gao, J.; Lebedev, O.I.; Turner, S.; Li, Y.F.; Lu, Y.H.; Feng, Y.P.; Boullay, P.; Prellier, W.; van Tendeloo, G.; Wu, T. Phase selection enabled formation of $\mathrm{M}$ abrupt axial heterojunctions in branched oxide nanowires. Nano Lett. 2011, 12, 275-280. [CrossRef] [PubMed]

22. Seo, K.; Yu, Y.; Duane, P.; Zhu, W.; Park, H.; Wober, M.; Crozier, K. Si microwire solar cells: Improved efficiency with a conformal $\mathrm{SiO}_{2}$, layer. Am. Chem. Soc. 2013, 7, 5539-5545.

23. Elbersen, R.; Tiggelaar, R.; Milbrat, A.; Mul, G.; Gardeniers, H. Controlled doping methods for radial p/n junctions in silicon. Adv. Energy Mater. 2015, 5, 1401745. [CrossRef]

24. Kayes, B.M.; Filler, M.A.; Henry, M.D.; Maiolo, J.R., III; Kelzenberg, M.D.; Putnam, M.C.; Spurgeon, J.M.; Plass, K.E.; Scherer, A.; Lewis, N.S.; et al. Radial PN junction, wire array solar cells. In Proceedings of the 2008 33rd IEEE Photovoltaic Specialists Conference, San Diego, CA, USA, 11-16 May 2008; pp. 1-5.

25. Levison, H.; Arnold, W. Handbook of Microlithography, Micromachinging, and Microfabrication; SPIE Press: Bellingham, WA, USA, 1997; pp. 463-465.

26. Ohring, M. Materrials Science of Thin Films. In Materrials Science of Thin Films; Academic Press: Cambridge, MA, USA, 2001; Chapter 1; ISBN 9780080491783.

27. Tong, J.; Ma, F.; Hoex, B.; Lennon, A. Tunnel oxides formed by field-induced anodization for silicon solar cell passivation. In Proceedings of the 2018 IEEE 7th World Conference on Photovoltaic Energy Conversion (WCPEC) (A Joint Conference of 45th IEEE PVSC, 28th PVSEC \& 34th EU PVSEC), Waikoloa Village, HI, USA, 10-15 June 2018; pp. 2078-2081.

(C) 2020 by the author. Licensee MDPI, Basel, Switzerland. This article is an open access article distributed under the terms and conditions of the Creative Commons Attribution (CC BY) license (http://creativecommons.org/licenses/by/4.0/). 